\title{
The Possibility of a Fair Play Account of Legitimacy
}

\author{
Justin Tosi, University of Arizona \\ forthcoming in Ratio
}

State legitimacy has traditionally been thought of as a claim right to be obeyed. But the literature on legitimacy has recently seen a significant conceptual revision. Several philosophers have argued that the state's right to rule—-the core element of state legitimacy—is better characterized not as a claim right to obedience, but as a power right. ${ }^{1}$ Surprisingly, there have been few attempts to show that traditional justifications for the claim right might also be used to justify a power right. And, even more surprisingly, there have been no such attempts involving the principle of fair play, which is widely regarded as the most promising basis for a claim right to obedience. ${ }^{2}$ In this paper, I address that oversight by explaining how the principle of fair play could generate a power right if its conditions are met. Doing so will involve responding to a recent argument from William Edmundson that purports to show that the principle is incapable of meeting this task. ${ }^{3}$ I show that the principle of fair play has untapped resources, apparently unnoticed by Edmundson and others, that allow it to generate a power right. Thus it offers one possible way of justifying the state, even as our understanding of what that task involves is changing.

\footnotetext{
${ }^{1}$ Arthur Isak Applbaum, "Legitimacy without the Duty to Obey," Philosophy \& Public Affairs 38, no. 3 (2010); David Copp, "The Idea of a Legitimate State," ibid.28, no. 1 (1999); William A. Edmundson, Three Anarchical Fallacies: An Essay on Political Authority (Cambridge: Cambridge University Press, 1998); Gerald F. Gaus, The Order of Public Reason: A Theory of Freedom and Morality in a Diverse and Bounded World (New York: Cambridge University Press, 2011); Kent Greenawalt, Conflicts of Law and Morality (New York: Oxford University Press, 1987); Stephen Perry, "Political Authority and Political Obligation," in Oxford Studies in Philosophy of Law: Volume 2, ed. Leslie Green and Brian Leiter (Oxford: Oxford University Press, 2013).

${ }^{2}$ On the popularity of fair play accounts of political obligation, see, e.g., Richard Dagger, "Philosophical Anarchism and Its Fallacies: A Review Essay," Law and Philosophy 19, no. 3 (2000); Ronald Dworkin, Law's Empire (Cambridge, Mass.: Belknap Press, 1986), 193; George Klosko, Political Obligations (Oxford: Oxford University Press, 2005).

${ }^{3}$ William A. Edmundson, "Political Authority, Moral Powers, and the Intrinsic Value of Obedience," Oxford Journal of Legal Studies 30, no. 1 (2010).
} 
The first section presents a brief overview of attempts to justify the claim right to obedience using the principle of fair play. I explain how justifying a power right is different and show how the principle can be adapted to this end in the second section. I consider two objections to the fair play account of the state's power right in the third section.

\section{Fair Play and the Claim Right to Obedience}

H. L. A. Hart provides the canonical formulation of the principle of fair play: "when a number of persons conduct any joint enterprise according to rules and thus restrict their liberty, those who have submitted to these restrictions when required have a right to a similar submission from those who have benefited by their submission." ${ }^{4}$ The intuitive idea at the heart of the principle is that we should do our fair share in supporting enterprises from which we benefit. Some political philosophers have argued that the state is such an enterprise, and that, accordingly, to receive its benefits is to incur obligations. Among these obligations, they argue, is a duty to obey the law, the correlative of which is a claim right to obedience.

Recent fair play theorists may be helpfully distinguished by how they respond to Robert Nozick's famous objections to the principle. Nozick presents compelling examples of benefits being foisted upon people, and objects that the mere provision of these benefits is not sufficient to generate obligations. ${ }^{5}$ Some have responded by arguing that mere receipt of benefits is not enough: people must accept the benefits willingly and knowingly, or see themselves as participants in the cooperative scheme that provides the benefits. Call theorists who respond this way voluntarists. ${ }^{6}$ Other theorists have argued that the mere provision of benefits is sufficient to

\footnotetext{
${ }^{4}$ H. L. A. Hart, "Are There Any Natural Rights?," Philosophical Review 64, no. 2 (1955): 185.

${ }^{5}$ Robert Nozick, Anarchy, State, and Utopia (New York: Basic Books, 1974), 90-95.

${ }^{6}$ They include Richard Dagger, Civic Virtues: Rights, Citizenship, and Republican Liberalism (New York: Oxford University Press, 1997), 69-70; John Rawls, "Legal Obligation and the Duty of Fair Play," in Collected Papers, ed.
} 
generate obligations, but only for a certain class of important goods (e.g. the rule of law, national defense, a livable environment). Call these theorists non-voluntarists. ${ }^{7}$

Theorists of each type claim that, once their various conditions are met, the state holds a claim right obedience on the part of subjects who have benefited, and those subjects have a correlative duty to obey. This is the current state of the literature on state legitimacy and fair play. But as I noted in the introduction, the criteria for success in a justification of the state have changed. If the principle of fair play is to remain relevant to this debate, it will have to be brought to bear on a different question. Both voluntarists and non-voluntarists can accept my extension of fair play to the justification of power rights.

\section{Fair Play and the Power Right to Rule}

As I noted at the start, political philosophers have recently expressed skepticism about the importance of a claim right to obedience for state legitimacy. David Copp, who has provided the clearest statement of the power right view of legitimacy, writes that "a legitimate state would have a...Hohfeldian power to put its citizens under a duty to do something." 8 The state’s right to rule is unlike a claim right, according to Copp, in that it consists largely of the ability to alter the rights and duties of its citizens. Legitimate states can “change the moral status of actions” —_by, for instance, rendering permissible actions impermissible, and vice versa. The right to rule is,

Samuel Richard Freeman (Cambridge, Mass.: Harvard University Press, 1999), 122; A. John Simmons, Moral Principles and Political Obligations (Princeton, N.J.: Princeton University Press, 1979), 107-08; Edward Song, "Acceptance, Fairness, and Political Obligation," Legal Theory 18, no. 2 (2012).

7 They include Richard J. Arneson, "The Principle of Fairness and Free-Rider Problems," Ethics 92, no. 4 (1982); Hart, "Are There Any Natural Rights?," 185; Klosko, Political Obligations. Though note that Simmons argues that Hart might be a voluntarist. See Moral Principles and Political Obligations, 108. Edmundson himself has also expressed some sympathy for non-voluntarist fair play obligations. See his "Locke and Load: A Review of A. John Simmons, Justification and Legitimacy: Essays on Rights and Obligations," Law and Philosophy 22, no. 2 (2003): 201-09.

${ }^{8}$ Copp, "The Idea of a Legitimate State," 19. Emphasis in original.

${ }^{9}$ Ibid., 20. 
therefore, better characterized as a power right: “an ability to cause, by an act of one’s own, an alteration in a person’s rights.” 10

A claim right to obedience would explain why subjects owe obedience to the state. A power right, on the other hand, explains the state's ability to put subjects under a duty, the performance of which is not necessarily owed to the state. These duties exist because of the state's exercise of its power right, but Copp and others argue that the latter is indispensable to an account of state legitimacy, and the general claim right to obedience is not.

Our question, then, is whether the principle of fair play can explain how a state could have this power right. William Edmundson argues that it cannot. Agents with power rights create what he terms intrinsic reasons for action—reasons that reflect "the action's inherent value."11 And at least part of the inherent value these actions have stems from their being part of a directive from an agent with a moral power. So if a state has a power right to rule its subjects, those subjects have intrinsic reason to comply with its directives. ${ }^{12}$

But Edmundson thinks that the participants of fair play schemes do not have intrinsic reason to comply with the directives of officials of their scheme. He introduces the following speed limit example to show that such directives generate mere coordination reasons-“'reasons intended to make salient a certain solution to a collective action problem.”13 He writes:

If the state decrees 'Drive 55!' and the practised solution is $65 \mathrm{mph}$, then the fairplay duty is to drive 65 not $55 \mathrm{mph}$. This would be so even if there would have been no drive-65 convention had the state not decreed a lower, 55-mph limit. Now suppose that the practised solution is indeed $55 \mathrm{mph}$, which matches the content of the state's directive. The directive is still at best a provisional reason to drive $55 \mathrm{mph}$; and any duty to comply stands free of the state's directive, in the

\footnotetext{
10 Judith Jarvis Thomson, The Realm of Rights (Cambridge, Mass.: Harvard University Press, 1990 ), 57.

${ }^{11}$ Edmundson, "Political Authority, Moral Powers, and the Intrinsic Value of Obedience," 184.

12 Edmundson has developed his view further in "Because I Said So," Problema: Anuario de Filosofía y Teoría Del Derecho 7 (2013).

13 "Political Authority, Moral Powers, and the Intrinsic Value of Obedience," 189.
} 
sense that there is no intrinsic reason to drive 55 , with or without an authoritative directive to do so. Given general compliance, there may indeed be a fair-play duty now, which does involve an intrinsic reason of some description. But the relevant description will not make essential reference to the state or its directives as the causal seed of the norm of conformity. ${ }^{14}$

In other words, the duty to obey fair play officials' directives is conditional on their directive actually being adopted as a coordination point that solves a practical problem. But even if the directive is adopted by the scheme, it is the effectiveness of the norm, and not the announcement of the directive, that creates the duty. This suggests that the officials, in making their directive, are not exercising a moral power, but rather a "side effect" power. ${ }^{15}$

The difference between side effect powers and moral powers is best explained by distinguishing two ways in which an act alters a normative situation. Side effect powers alter the normative situation causally. Rickey exercises a side effect power when he destroys Kirby's property, as Kirby now has a claim right to restitution from Rickey. But if Kirby transfers his property to Rickey, thus giving Rickey a claim right to it, Kirby has normatively altered the normative situation. He has exercised a moral power. In Edmundson’s view, fair play directives change the world by causally altering peoples' behavior, and in doing so change peoples' duties. If they were authoritative directives - i.e. exercises of a moral power — then they would change peoples' duties without needing to change the world first. So officials in fair play schemes do not have power rights.

I think that there are two historically neglected elements of the principle of fair play that allow for a compelling defense of the fair play justification against Edmundson's argument. First, there is Hart's stipulation in the formulation quoted above that cooperative schemes

\footnotetext{
${ }^{14}$ Ibid.

15 The term originates in David M. Estlund, Democratic Authority: A Philosophical Framework (Princeton, N.J.: Princeton University Press, 2008), 143.
} 
justified by the principle of fair play be conducted "according to rules." And second, there is the fact that it admits of a subtle but important distinction between the grounds of authority, and the grounds of the authoritative force of a particular directive.

Rules are of critical importance to the idea of fair play. For one thing, they are what separate fair play obligations from other, more open-ended reciprocity obligations-like obligations of gratitude. So the existence of rules is necessary for the principle of fair play to be applicable. But more fundamentally, the rules of a cooperative scheme specify what it means to play fair. There are, of course, limits to what the rules can be for a scheme to qualify as fair, but the specific content of fair play depends on the rules of the scheme. ${ }^{16}$ It is not up to the judgment of individual participants to determine what being fair to other participants might involve. What participants in a cooperative scheme owe to one another is submission to the rules. The currency with which one must repay one's debt of fairness is specified by the rules of the scheme.

For present purposes, it is enough to say that a cooperative scheme exists if and only if there are rules regulating the distribution of the scheme's benefits and burdens. The more pressing issue is that of what it means for these rules to exist. One requirement for the existence of a rule is the recognition of its existence. Hart famously argued that this recognition can come in either of two forms: in the rule being practiced (as in systems of primary rules), or in its validity according to the scheme's rule of recognition (as in legal systems). ${ }^{17}$ The other requirement for the existence of a rule is an element of normativity that is missing from coordination points. The latter exist when there is some pattern of behavior converging on a

\footnotetext{
${ }^{16}$ At minimum, the rules would have to result in a distribution of benefits and burdens that is both fair and worth each participant's effort. Klosko, Political Obligations, 6.

${ }^{17}$ See H. L. A. Hart, The Concept of Law, 2nd ed. (Oxford: Clarendon Press, 1994), 9-11; Scott Shapiro, Legality (Cambridge, Mass.: Harvard University Press, 2011), 90. These existence conditions are drawn from Hart.
} 
shared strategy for addressing a problem. But there is more to rules than patterns of behavior. Rules must be regarded as requirements that those bound by them ought to follow, and not merely as guides for predicting behavior. In systems of primary rules, most of those bound by the rules must think of them this way. But in systems with a rule of recognition, only the officials need to think this way about the primary rules. Ordinary participants can still be cooperating in the relevant way, for purposes of the principle of fair play, if they simply recognize the validity of primary rules.

Returning again to Edmundson's speed limit example, it is not clear from the description that there are any rules in place. Edmundson mentions a "norm of conformity", but norms include coordination points and rules (among other types of requirements). Talk of a "practised solution" suggests a coordination point. If there are not even primary rules, then this is not a cooperative scheme conducted according to rules. Then fair play duties could not arise, and this case could not be a counterexample to the principle of fair play. But since our question requires such a scheme, let us assume that the speed limit is a primary rule. Then participants could have a fair play duty to follow it, and a corresponding claim right against one another that it be followed. The objection posed by the example is that the officials can have no power right to impose this duty, or at least no power right justified by the principle of fair play. Rather, they can only make a suggestion that they hope becomes a rule because it is practiced.

In some situations, this claim is true. Cooperative schemes vary in structure and complexity. Some are simple, and have a few specific aims with no need for anything but primary rules or positions other than "participant.” If changes to the primary rules in schemes like these are necessary, they may happen gradually and informally, or as a result of recognition through practice of a new proposal, just like Edmundson says. But other schemes—like states- 
have complex, open-ended aims and require a variety of rules and a complicated structure of positions with various extra powers and liberties. Schemes of this latter sort have rules about rules (what Hart called secondary rules), including rules allocating the ability to change primary rules, and a rule of recognition by which primary rules can be valid regardless of whether they are being practiced. Officials in these schemes are not creating rules through mere side effect powers, as in the speed limit example. They are using the powers associated with their position in the scheme to create rules. In other words, the secondary rules empower these officials not merely to propose rules that may then become valid through being practiced. Rather, the rulegiven power of their position enables officials actually create new rules simply by declaring them valid.

What remains to be explained is what these secondary rules and the powers they confer have to do with power rights. I mentioned above that participants in fair play schemes have claim rights against one another that they all must submit to the scheme's primary rules. The same is true of the scheme's secondary rules. When people become subject to fair play schemes, whether by accepting or merely receiving their benefits, the rules of the scheme specify the terms of their cooperation - their "similar submission." In this way the principle of fair play turns the rules of the scheme (and the rights they specify) into moral requirements.

A comparison to consent theory will be illuminating. Fair play is, like consent, a transactional principle-it explains the allocation of rights between persons by appeal to facts about some dealing between them. According to the consent tradition, rights are conferred when parties agree to a contract, and the terms of the contract specify the rights to be conferred. The principle of fair play, on the other hand, holds that a reallocation of rights may be triggered by acceptance or receipt of benefits. And just as contracts specify the changes to parties' rights and 
duties when they consent, the rules of a fair play scheme specify the changes to parties' rights and duties upon incurring a debt of fairness. As we have seen, the rules of a fair play scheme may allocate powers through secondary rules. So just like consent, fair play is capable of generating a complex system of rights, including power rights, by making the rules of the scheme into moral requirements. ${ }^{18}$

The rules element, then, shows that the principle of fair play has the machinery to generate power rights. But part of Edmundson’s challenge remains to be answered. His speed limit example seems to show that, even if a directive from a fair play official results in a change to the moral landscape, it does so only after the directive has been adopted as a rule and produces benefits. If Edmundson is right about this, then it would seem that every putative exercise of a power right (as provided in the rules) by a fair play official has no moral force until it is adopted by the participants. We would expect an institution with political authority to have a standing normative power to issue commands. But the fair play justification seems to say that the exercise of the power right precedes its justification. This is odd at best.

Fortunately, there is a way of interpreting the speed limit example that is more flattering for the fair play justification. The trouble with the example is that it is considered in isolation from its systemic context. This is significant, because the principle of fair play is supposed to justify a rule-based cooperative scheme in its entirety, not individual rules or coordination

\footnotetext{
${ }^{18}$ Note that the principle of fair play does not collapse into the principle of consent because of this similarity in structure. If I jump the turnstiles to ride the subway, I have given no sign of consent to anything, but I have accepted benefits and free-ridden on the efforts of others. My action is wrong because it is unfair, even though it violates no contractual agreement. It might be objected that jumping the turnstiles is a sign of tacit consent. If this is so, then even in this case fair play is not separable from consent. But jumping the turnstiles is plainly not a sign of consent, as it does not conventionally signal that the jumper agrees to the same terms as paying riders - quite the opposite, in fact. And in any case, it would not be an instance of tacit consent, as the alleged sign is not given by remaining silent or inactive. For more on the independence of the principle of fair play from consent, see A John Simmons, "The Principle of Fair Play," Philosophy \& Public Affairs 8, no. 4 (1979). On the conditions of tacit consent, see Simmons, Moral Principles and Political Obligations, 80-83.
} 
proposals. So the relevant question in the example should be one of whether there is an ongoing cooperative scheme in which participants enjoy a fair distribution of benefits from following the rules, including a secondary rule that permits the officials to change primary rules about, for example, the speed limit. If there is—and in reasonably just states, there is—-then the officials issuing the directive have a power right.

The point is, perhaps, obscured by the fact that the fair play justification is based in reciprocity. Participants owe a debt of fairness in exchange for benefits made possible by others' submission to rules. So it is natural to ask how one could be liable to have one's duties changed by a directive from a cooperative scheme before that directive has resulted in one being provided with benefits. If a rule is not yet effective, then it is not clear how one could have benefitted in the relevant way.

The fair play justification can avoid this concern by distinguishing, as I suggested above, between the grounds of the authority—-the moral power right—of fair play officials, and the authoritative force of their individual directives. The power right is grounded in the debt of fairness that participants owe to the other participants of the scheme for their submission to the total system of rules. And individual directives have authoritative force because they are exercises of the power right that is justified by the principle of fair play. In other words, directives do not require individual justification. Instead, we should think of them as counting toward the total balance of the debt of fairness that justifies the entire scheme. If a directive results in a change in the distribution of benefits and burdens, then it could result in the cooperative scheme becoming unfair, and so losing its power right. But in cases like Edmundson's speed limit example, it is unlikely that such a directive would be costly enough to 
make the scheme no longer fair or worth participating in. And legitimate states are generally in this position when they issue new directives.

In short, I think that the principle of fair play is well-suited to provide an explanation of how political authorities acquire moral powers. The principle holds that the rules of a cooperative scheme specify the terms of fair cooperation. Once we remember that the rules governing cooperative schemes can include secondary rules, we are able to see that the principle of fair play can generate genuine moral power rights. And we can see that the justification for these rights precedes their exercise once we understand that fair play justifies rules as a system rather than individually.

\section{Objections}

I noted in my reply to Edmundson in section II that states are generally in the position of having already provided benefits when they issue directives to change primary rules. To this it might be objected that the initial establishment and exercise of the state's moral power remains troubling on the fair play account. If the state has not provided those it claims as subjects with benefits, then its proposed directives can provide no more than coordination reasons, as Edmundson says.

I have two replies to this objection. First, it may be possible to give a fair play account of the establishment of a legitimate state that does not include an initial reliance on coordination reasons. A legitimate state might begin as a cooperative scheme of a relatively small group, the members of which are active in setting up the scheme at the outset. The scheme could then gradually expand in scope, with more and more people receiving or accepting its benefits and burdens (including its secondary rules), until it is extensive enough to qualify as a state. If a state began this way, then there would be no need to rely on coordination reasons as the objection claims. 
I am not especially worried about whether such a story could work, though, becauseand this is the second reply—-there is nothing about the fair play justification that speaks against the possibility of other justifications of state authority. ${ }^{19}$ If it should turn out that, say, only a consent account can provide an adequate explanation of the initial establishment of state authority, the fair play account might fare better in other circumstances. For example, fair play might better explain why subjects of a state outside of the first generation of citizens are liable to its authority. ${ }^{20}$ Political authority is difficult to justify for different reasons in different circumstances. There is no reason to think that a valid account must work in all of them. So if the fair play account can only explain why a legitimate state can continue to have authority, but not how it initially comes into authority, then it is still interesting and worthwhile. And since it seems to work best at justifying cooperative schemes that provide benefits in an ongoing basis, like existing modern states, it is all the more so.

It might also be objected that my introduction of secondary rules into the possible terms of fair cooperation runs counter to the intuitive force of the principle of fair play. The intuitive idea, as I noted above, is that people should do their fair share in supporting the practices and institutions from which they benefit. It may be historically interesting to some philosophers that Hart included the phrase "according to rules" in his original formulation of the principle of fair play, but this does not show that recognizing secondary rules, and in particular being liable to a state, is any part of playing fair. Justifying secondary rules seems different enough from holding

\footnotetext{
${ }^{19}$ One recent and promising development is the call for pluralist or multiple principle accounts of political obligations. E.g. Klosko, Political Obligations, 98-121; Jonathan Wolff, "Political Obligation: A Pluralistic Approach," in Pluralism: The Philosophy and Politics of Diversity, ed. Maria Baghramian and Attracta Ingram (London: Routledge, 2000).

${ }^{20}$ Consent theory's shortcomings outside of the first generation of a political community are well-known. See Simmons, Moral Principles and Political Obligations, 60-61, 95-100.
} 
that one should do one's fair share that a connection between the two ideas needs to be made explicit.

Fortunately, I think that we can derive the “according to rules” clause quite clearly from the intuitive heart of the principle of fair play. Part of the cost of cooperating with others is in giving up the liberty to decide what one does, unencumbered by the (morally justified) demands of others. Rules of change are an extension of this idea. Their inclusion among the rules of a cooperative scheme signals not only that the form of your support for the scheme is not up to you, but that the scheme can also alter the form of your required support. ${ }^{21}$ If people do not relish submitting to secondary rules, this should come as no surprise. To submit to them is to take on a cost, just as one does when submitting to a primary rule. Whether this cost is so burdensome that it outweighs whatever benefits the scheme provides is another question. The point is that being governed by rules, including secondary rules, is part of the idea of doing one's part in supporting a cooperative scheme.

\section{Conclusion}

Despite its popularity in the literature on political obligation and the claim right to obedience, the principle of fair play has been largely ignored in recent attempts to justify state power rights. William Edmundson argues that this is no mistake, as fair play directives seem more like exercises of a side effect power than of a power right. I have tried to show that Edmundson's account of fair play directives is inaccurate, at least in complex cooperative schemes, and that the fair play account of political obligation can be extended to generate power rights. This

\footnotetext{
${ }^{21}$ At least it is not necessarily up to you. A cooperative scheme might very well allow that its members have some collective power in changing the rules, or that individuals have some discretion in determining how they support the scheme.
} 
represents the removal of a significant obstacle to applying the principle of fair play to the recently recast debate on state legitimacy. 


\section{Bibliography}

Applbaum, Arthur Isak. "Legitimacy without the Duty to Obey." Philosophy \& Public Affairs 38, no. 3 (2010): 215-39.

Arneson, Richard J. "The Principle of Fairness and Free-Rider Problems." Ethics 92, no. 4 (1982): 616-33.

Copp, David. "The Idea of a Legitimate State." Philosophy \& Public Affairs 28, no. 1 (1999): 345.

Dagger, Richard. Civic Virtues: Rights, Citizenship, and Republican Liberalism. New York: Oxford University Press, 1997.

. "Philosophical Anarchism and Its Fallacies: A Review Essay." Law and Philosophy 19, no. 3 (2000): 391-406.

Dworkin, Ronald. Law's Empire. Cambridge, Mass.: Belknap Press, 1986.

Edmundson, William A. "Because I Said So." Problema: Anuario de Filosofía y Teoría Del Derecho 7 (2013): 41-61.

- "Locke and Load: A Review of A. John Simmons, Justification and Legitimacy: Essays on Rights and Obligations." Law and Philosophy 22, no. 2 (2003): 195-216.

. "Political Authority, Moral Powers, and the Intrinsic Value of Obedience." Oxford Journal of Legal Studies 30, no. 1 (2010): 179-91.

- Three Anarchical Fallacies: An Essay on Political Authority. Cambridge: Cambridge University Press, 1998.

Estlund, David M. Democratic Authority: A Philosophical Framework. Princeton, N.J.: Princeton University Press, 2008.

Gaus, Gerald F. The Order of Public Reason: A Theory of Freedom and Morality in a Diverse and Bounded World. New York: Cambridge University Press, 2011.

Greenawalt, Kent. Conflicts of Law and Morality. New York: Oxford University Press, 1987.

Hart, H. L. A. "Are There Any Natural Rights?". Philosophical Review 64, no. 2 (1955): 175-91.

—. The Concept of Law. 2nd ed. Oxford: Clarendon Press, 1994.

Klosko, George. Political Obligations. Oxford: Oxford University Press, 2005.

Nozick, Robert. Anarchy, State, and Utopia. New York: Basic Books, 1974.

Perry, Stephen. "Political Authority and Political Obligation." In Oxford Studies in Philosophy of Law: Volume 2, edited by Leslie Green and Brian Leiter, 1-74. Oxford: Oxford University Press, 2013.

Rawls, John. "Legal Obligation and the Duty of Fair Play." In Collected Papers, edited by Samuel Richard Freeman, 117-29. Cambridge, Mass.: Harvard University Press, 1999.

Shapiro, Scott. Legality. Cambridge, Mass.: Harvard University Press, 2011.

Simmons, A John. "The Principle of Fair Play." Philosophy \& Public Affairs 8, no. 4 (1979): 307-37.

Simmons, A. John. Moral Principles and Political Obligations. Princeton, N.J.: Princeton University Press, 1979.

Song, Edward. "Acceptance, Fairness, and Political Obligation." Legal Theory 18, no. 2 (2012): 209-29.

Thomson, Judith Jarvis. The Realm of Rights. Cambridge, Mass.: Harvard University Press, 1990. 
Wolff, Jonathan. "Political Obligation: A Pluralistic Approach." In Pluralism: The Philosophy and Politics of Diversity, edited by Maria Baghramian and Attracta Ingram, 179-96. London: Routledge, 2000. 